\title{
Die NHKA op reis na inklusiwiteit II: 'n Holistiese teo-antropologie as voorwaarde vir ekklesiologie
}

\author{
Authors: \\ Tanya van Wyk $^{1}$ \\ Johan Buitendag ${ }^{1}$ \\ Affiliations: \\ ${ }^{1}$ Department of Dogmatics \\ and Christian Ethics, \\ University of Pretoria, \\ South Africa \\ Correspondence to: \\ Tanya van Wyk \\ Email: \\ tanya.vanwyk@up.ac.za \\ Postal address: \\ Faculty of Theology, \\ University of Pretoria, \\ Lynnwood Road, Hatfield \\ 0083, Pretoria, South Africa \\ Dates: \\ Received: 02 Sept. 2011 \\ Accepted: 06 Sept. 2011 \\ Published: 04 Nov. 2011 \\ How to cite this article: \\ Van Wyk, T. \& Buitendag, J., \\ 2011, 'Die NHKA op reis na \\ inklusiwiteit II: 'n Holistiese \\ teo-antropologie as \\ voorwaarde vir ekklesiologie', \\ HTS Teologiese Studies/ \\ Theological Studies 67(3), \\ Art. \#1173, 10 pages. http:// \\ dx.doi.org/10.4102/hts. \\ v67i3.1173
}

C 2011. The Authors. Licensee: AOSIS OpenJournals. This work is licensed under the Creative Commons Attribution License.
The NRCA en route to inclusivity II: A holistic theological anthropology as condition for ecclesiology

This second article further examines the hypothesis that the fragmentation in the ecclesiology of the Netherdutch Reformed Church (NRCA) is based on a fragmented understanding of humanity. The concept of fragmentation is considered as the result of a positivistic epistemology with regard to understanding the ontology of humankind. In light of this, the NRCA's understanding of humanity is examined as it appeared in the Church's polity of 'no equalisation' with regard to the justification of separate ethnic-based churches and the Church's current understanding of homosexuality. The content of an inclusive theological anthropology is considered and suggested for the Church as a necessary step on its journey towards inclusivity.

\section{Inleiding}

In die aanloop tot hierdie artikel is dit aangetoon dat die spanning in die Nederduitsch Hervormde Kerk (NHKA) oor die betekenis en reikwydte van inklusiwiteit en diversiteit in die Kerk op 'n gefragmenteerde ekklesiologie berus. Hierdie gefragmenteerde ekklesiologie het geblyk uit die onderskeid (en skeiding) wat sommige van die Hervormde Kerk se teoloë in die verlede gemaak het, en tans nog doen, te wete die onderskeid tussen die sigbare kerk en die onsigbare kerk. Dit is aangetoon dat laasgenoemde berus op die spanning in die verstaan van die relasie tussen eenheid en eendersheid en verskeidenheid en geskeidenheid. Dit het destyds uitgekristaliseer in die NHKA se regverdiging van Artikel III, die volkskerkteologie en die Hervormde Kerk se verstaan en hantering van homoseksuele persone. Die hipotese dat hierdie fragmentasie in die ekklesiologie gegrond is op 'n gefragmenteerde mensbeskouing word in hierdie tweede artikel verder ondersoek.

\section{Fragmentasie: 'n Positiwistiese epistemologie}

Met die begrip fragmentasie word gepoog om 'n konsep te vind om die gediskonnekteerdheid en verdeling wat kenmerkend is van die diskoers oor inklusiwiteit en diversiteit in die NHKA, te beskryf. Volgens die woordeboek van die Afrikaanse taal dui fragmentasie op 'n proses waarin brokstukke van die geheel afgebreek het en afgesonder en verwyderd van die geheel geword het (Odendal e.a., [1965] 1988:230). Om te fragmenteer is om iets in bepaalde stukke of fragmente te verdeel of te breek sonder om die geheel enigsins te verreken.

Die begrip fragmentasie is reeds elders in verskeie vakdissiplines aangewend om verdeling en gediskonnekteerheid aan te toon. In die inligtingstegnologie verwys fragmentasie op 'n rekenaar na die rekenaarsisteem wat nie in staat is om ' $n$ datalêer as ' $n$ volledige eenheid te stoor nie en gevolglik die lêer in stukke verdeel en dit tussen-in ander datalêers stoor. Vanuit die sosiologie word fragmentasie in verband gebring met die proses van spesialisasie binne ' $n$ bepaalde vakgebied:

Each fragment split off as its body of knowledge became unmanageably large and as specialization within the fragment set in ... [it cannot be] denied that each discipline does have a different perspective reflected in its subfields ... there is sense in developing these perspectives to the fullest ... yet specialization must not be allowed to encourage us, ostrich like, to stick our heads in the sand and ignore what surrounds us. ${ }^{1}$

(Dogan \& Pahre 1989:72)

Vanuit die praktiese teologie word fragmentasie in verband gebring met 'n samelewing wat nie in staat is om diversiteit en pluraliteit te verdiskonteer nie (Gerkin 1997:101). Piaget (1970:13) meen dat fragmentasie verband hou met 'n bepaalde verstaan van die aard van kennis: '... $[P]$ rogress towards greater knowledge requires that problems should be identified and that those on which no agreement is possible at a given moment should be set aside and all attention focused on subjects in which verification is possible'.

1.Daar is ' $n$ fyn dialektiek tussen spesialisasie van kennis binne 'n bepaalde vakgebied en fragmentering wat neerkom op eensydige beklemtoning van ' $n$ deel van daardie vakgebied wat in die isolasie van daardie deel ontaard. Fragmentasie verwys na laasgenoemde, nie eersgenoemde nie. 
Dit kan gestel word dat fragmentasie 'n modernistiese onderneming is waarin daar op 'n gegewe moment op 'n bepaalde aspek of fragment gefokus word. Dit word gedoen ter wille van sogenaamde volledige kennis, maar dit lei uiteindelik totisolasieen reduksie. Diegeheelword gereduseer tot die onderdeel. Hierdie kompartementalisering van die werklikheid bring ' $n$ verskraling in werklikheidsverstaan mee. In terme van die inligtingstegnologie-analogie waarna bo verwys is, veroorsaak fragmentasie net verdere fragmentasie, aangesien toenemend meer datalêers in stukke verdeel moet word om in beskikbare oop ruimtes gestoor te word en beskikbare spasie dus akkumulatief minder word.

Onderliggend aan fragmentasie is dus die vooronderstelling dat kennis in afgegrensde, gefragmenteerde kompartemente kan bestaan. Dit veronderstel verder, op modernistiese wyse, dat objektiewe, eksakte kennis verkrygbaar is. Dit hou verband met 'n optimisme oor die mens se vermoë om volledig te ken en is gesetel in die idee dat kennis en sogenaamde waarheid op óf aangebore kennis wat intrinsiek aan die mens is, óf ervaring deur sintuiglike menslike vermoëns berus (kyk Ward 2003:9). Hierdie was die gronde van die modernisme (Ward 2003:4), en kom neer op 'n positiwistiese kennisleer of epistemologie - 'n optimisme oor die objektiwiteit van kennis.

Die rasionalisme was optimisties oor die mens se vermoë om deur rasionele denke kennis (of die waarheid) te bekom, aldus Renè Descartes se bekende uitgangspunt cogito ergo sum. Die empirisme weer was optimisties oor die mens se vermoë om deur empiriese waarneming (en uiteindelik verifikasie) kennis te bekom. Dit was die Weense Kring (Wiener Kreis) wat gepoog het om sin en on-sin van mekaar te skei deur die beginsel van verifikasie. Hiervolgens was die betroubaarheid van waarheid en kennis meetbaar deur gebruik te maak van logika (die rede) en ook empiriese waarneming (ervaring). Dit is deur die groep beskryf as logiese positiwisme (McGrath 2001:232, vgl. Van den Brink in Gaum 2008:886).

Die basis van beide die rasionalisme en die empirisme (wat uitgekristaliseer het in 'n optimisme oor die aard van kennis en die mens se vermoë daartoe) word onderskeidelik by Plato en Aristoteles se filosofie oor die werklikheid gevind. Plato (Timaeus 49a6-50b5) verdeel die werklikheid in twee sfere: die wêreld van idees of vorms en die wêreld van verskynings (kyk ook Plato, Phaedo 70c-d, 72a, in Burnett [1900], Platonis Opera. Volume 1, 1.57a-118a, edited by Burnett, J. [1900] 1967). Die eerste is die eintlike werklikheid en die tweede is die oneintlike werklikheid. Die sfeer van idees en vorms bevat die bloudrukke vir alles en dit wat ons met ons sintuie waarneem is eintlik net flou afskynsels van die idee of vorm in die wêreld van idees (vgl. Allen 1985:18-20; Cornford [1935] 1997:178-180). Die stoflike/aardse/vleeslike/liggaamlike word dus geminag.

Aristoteles weer het, anders as Plato, induktief te werk gegaan en die werklikheid in kategorieë verdeel: substansie en kwaliteit (Aristoteles, Categoriae 2.1a.17-23; Metaphysica 1.1028b.2-4; vgl. Eslick 1958:503-513). Substansie is verder in primêre (individueel) en sekondêre (genera) substansies verdeel, en kwaliteit in essensiële kwaliteite en toevallige kwaliteite (Allen 1985:94). Dit het berus op empiriese waarneming en is uitgewerk volgens die doel van elke kategorie. Hierdie kenteorieë van Plato en Aristoteles het gepaard gegaan met bepaalde mensbeskouings. Plato het die mens in dele verdeel en Aristoteles het die mens in terme van die doel van die mens beskou (entelegie). Beide het 'n gefragmenteerde mensbeskouing tot gevolg.

Plato het die mens se wese as bestaande uit twee dele beskou: die mens het ' $n$ liggaam wat onderwerp is aan die sintuie en 'n siel waar die mens se rede aangetref word (Allen 1985:55). Plato het ook die liggaam met die siel gekontrasteer (kyk Buitendag 2008:6, vgl. Murphy 1998:2). Aristoteles kompartementaliseer nie die siel en die liggaam nie - die siel is die vorm van die liggaam, maar bestaan nie onafhanklik nie. Hy het 'n onderskeid gemaak tussen potensialiteit en aktualiteit en geargumenteer dat 'n onderwerp se vermoë om te kan verander intrinsiek aan die onderwerp se wese is. Hierdie 'eintlikheid' of vorm is vir Aristoteles substansie in die volle sin van die woord. Daarom is vorm en telos vir Aristoteles uitruilbare begrippe. Die etiek van Aristoteles was daarom uitkomsgerig. Die korrekte keuse word bepaal deur die eindpunt - die doel van iets (Allen 1985:94). Aristoteles het dus die wese van die mens in terme van die telos, die doel van menswees verstaan. In sy Ethica Nichomachea (IX.4) beskryf Aristoteles (in Bywater [1894] 1962) telos as eudaimonia en sê dat 'wat vir die mens goed is, vind die resultaat in die aktiwiteit van die siel wat deug (virtue) voortbring' (kyk Ackrill 1997, hoofstuk 11; vgl. Vardy 2009:74).

Albei perspektiewe fragmenteer deur of in dele te verdeel (Plato) en of die doel van elke deel bepalend te maak vir die ontologie van elke deel (Aristoteles). Hierdie fragmentasie het' $n$ rol gespeel in die ontwikkeling van die kerk se verstaan van menslike seksualiteit (Vardy 2009:75).

Enersyds is die vleeslike, en alles wat daarmee verband hou soos seks en seksualiteit, in terme van Plato se verstaan van die ondergeskiktheid van die liggaam (vleeslike of aardse) beskou. Dit is later deur Augustinus en Thomas Aquinas (kyk Nichols 1998:101) verder ontwikkel. Hulle het Plato se antropologiese dualisme verwerk tot die gedagte dat die liggaam verwerplik en vleeslik is (vgl. Allen 1985:56). Augustinus is hierin ook deur Plotinus beïnvloed (Cavadini 1999:656). Plotinus het die siel as 'n substansie beskou wat in staat is om apart, sonder die liggaam, te bestaan. Die materiële aspek van die sintuiglike werklikheid is 'boos' en die siel beheer die materiële werklikheid vanaf die binnekant af. Hy bring menslikheid in verband met die sogenaamde Laer Siel, teenoor die Hoër Siel. Die enigste manier om van die Laer Siel ontslae te raak is om kennis in te win. Hierdie verstaan van Plotinus lei Augustinus dan om te oordeel dat mense rasionele siele is met liggame wat deur ons gebruik word (Allen 1985:89). Laasgenoemde word bevestig deur Augustinus se klem op die siel as geestelike substansie wat toegang tot werklike kennis het. Augustinus (De bono coniugali 6.6; 8.8; kyk Børresen [1968] 1981:94-123) het dus seksualiteit 
negatief beoordeel omdat hy gemeen het seks kompromitteer die mens se rede en denke - aldus Plato (Vardy 2009:50).

Andersyds is die doel van die mens se bestaan deurgetrek tot die doel van elke liggaamsdeel, wat onder meer gelei het tot die vasstelling van norme aangaande sogenaamde normale seksualiteit, wat onder meer homoseksualiteit nie insluit nie (Kantor 1998:6-7; kyk ook Blumenfeld 1992; Dreyer 2006). Die teologiese dimensie hiervan is deur Thomas Aquinas (Summa Theologiae, c. 1265-1273 CE) tot Aristoteles se filosofie oor die mens toegevoeg (Vardy 2009:49 e.v.). Dit blyk duidelik dat die gemene deler tussen al hierdie sake 'n fragmentasie in werklikheidsverstaan, epistemologie en antropologie is.

In teenstelling met die moderniteit, en die rasionalisme en empirisme waarop dit berus, het die postmoderniteit die moderniteit se strewe na objektiewe, afgegrensde eksakthede as futiel uitgewys (Ward 2003). Binne die postmoderne kennisteorie word die begrip antifoundationalistic in verband gebring met die teorie van dekonstruksie. Vir die leser of kommunikeerder wat tegelyk ook die interpreteerder is, beteken dit die bewuswording van die eie syn (eie subjektiewe kontingensie) en die vraag na watter rol dit in kommunikasie, lees en interpretasie speel (Smith 2006:134). Die begrip demistifikasie word verder met die teorieë van dekonstruksie en antifoundationalism in verband gebring, daar dit probeer aantoon dat aannames wat beweer word van 'n natuurlike aard te wees, in werklikheid ideologiese projeksies is (Van Aarde 2005a, 2007:19). Daarom kan demistifikasie ook ideologiekritiek genoem word. In hierdie sin dui dit op die blootlegging van universele kategorieë wat as skerm dien vir ideologiese motiewe wat polities, ekonomies of kultureel van aard kan wees.

Immanuel Kant het vroeër in die geskiedenis van die hermeneutiek daarop gewys dat objekte aan die kennende subjek verskyn na gelang van die vrae wat die subjek vra (Van Aarde 2005a:1). Daarmee verwerp hy die positiwistiese gedagte van kennis, naamlik dat kennis gegrond is in rasioneel kontroleerbare en geobjektiveerde eksakthede.

Ook Habermas se kritiese teorie het hierdie positiwistiese verstaan van kennis teengestaan. Die bedoeling van Habermas was om die belang wat onderliggend aan alle strewes na kennis was bloot te lê en daarop te wys dat kennis nie'n sogenaamde suiwer weerspieëling van die werklikheid is nie. Geen kennis is belangevry nie (Van Aarde 2007:8). Dit kom daarop neer dat agter die mens se verstaanproses bepaalde belange lê wat die verstaanproses en die inhoud van verstaan bepaal. Volgens Van Aarde (2007:15) konstrueer Habermas 'n eksistensiehermeneutiek met grondige sensitiwiteit vir die distorsies in die taalhandeling wat ons ideologies gesanksioneer vind in tradisies. Ook Ricoeur (1974) het geoordeel dat hermeneutiek en kritiese teorie nie uitsluitend van aard is nie en dat die kritiese beoordeling van individue se vooroordele (prolegomena) deel van die hermeneutiek moet wees (vgl. Jensen 2007:143-150).
Fragmentasie is dus die produk van 'n poging om by eksakthede uit te kom en dit gaan gepaard met ontologiese aannames. In die ekklesiologie van die NHKA is die kerk verdeel in nou-hiernamaals/sigbare-onsigbare/kerkkoninkryk-gedeeltes of brokstukke. Daarom is die begrip fragmentasie aan hierdie verdeling gekoppel. Hierdie fragmentasie berus op dieselfde fokus op 'n bepaalde fragment of brokstuk van die mens. Dit sal vervolgens aangetoon word.

\section{Die NHKA en die beginsel van geen gelykstelling}

In Artikel III van die destydse kerkwet van die NHKA is dit gestel dat die Hervormde Kerk geen gelykstelling in sy (sic) midde toelaat nie op grond van die gevare wat die vermenging van Blank en Nie-Blank inhou (NHKA 1951). In die regverdiging van die NHKA se apostolaatsbeleid en aparte volkskerke gebruik Storm (1992:929) ook die beginsel van geen gelykstelling. Ook Wolmarans (in Van Wyk 1978) beskryf die 'Christelike plig van Blankes teenoor die NieBlankes in Suid-Afrika' in terme van die beginsel van 'geen gelykstelling':

Dit is baie duidelik dat die Voortrekkers ' $n$ sterk roepingsbesef gehad het teenoor die inboorlingrasse van Suid-Afrika. Hulle moes die rasse help om kultureel te ontwikkel en hulle moes volgens die opdrag van Christus self aan hulle die evangelie verkondig ... Dat hulle in hierdie verband die onderhorigheid van die Nie-Blanke en geen gelykstelling nie as noodsaaklik geag het, is net so min ' $n$ bewys van diskriminasie as wat ouerlike gesag teenoor die kind vir diskriminasie aangesien kan word.

(Wolmarans in Van Wyk 1978:25)

Uit hierdie opmerking van Wolmarans blyk dit dat Blankes en Nie-Blankes nie op dieselfde vlak (geen gelykgestelling nie) geplaas kan word nie, omdat die Blanke die voog is en die Nie-Blanke die kind. Daar is dus 'n verskil in rangorde. Hierdie verskil in graad of rangorde berus vir Wolmarans in ' $n$ bepaalde verstaan van die waarde van die mens wat na die beeld van God geskep is en ook implisiet dat een kultuur 'beter' as ' $n$ ander is. In Wolmarans se artikel 'Menswaardigheid en menslike regte na aanleiding van die Skrif' (Wolmarans in Van Wyk 1978), koppel hy menswaardigheid aan die mens wat na die beeld van God geskep is. Hierdie beeldskap van God (in mens) is verbind aan die mens se verhouding met God:

hy [as verwysend na die mens] sou die Woord van God hoor, as God met hom spreek, met ander woorde hy sou in voortdurende woordverbinding met God staan. Dit beteken dat sy waardigheid en waarde altyd sou afhang van hierdie verhouding tot God ... Die grond van sy menswaardigheid was die bande van gehoorsaamheid aan God.

(Wolmarans in Van Wyk 1978:83)

In aansluiting hierby meen Wolmarans (1962) - weer eens vanuit die implisiete perspektief dat sekere kulture meer 'primitief' is - dat:

ervarings met die Boesmans het uitgewys dat hulle, nadat hulle 'makgemaak' is, tog nie onvatbaar is nie vir elementêre beginsels van die westerse beskawing ... die feit dat al hierdie gekleurde 
rasse net in graad van beskawing van die Blankes verskil en dus as mede-skepsels na die beeld van God beskou behoort te word, het die Calvinistiese Christen gedwing om 'n nader houding teenoor die inboorlinge aan te neem as teenoor al die ander lewende wesens. Tog is dit waar dat daar Blankes was, wat dit met groot erns betwyfel het dat die primitiefste onder die primitiewes vatbaar kon wees vir die Evangelie en dat daar plek vir hulle in die Hemel kon wees. Maar dit geld die uitsonderings.

(Wolmarans 1962:87)

Dit blyk dat Wolmarans onder meer gemeen het dat die mens se waarde en waardigheid voorwaardelik toegeken is op grond van geloof in God. Hy meen verder dat geloof 'n onbetwisbare stempel op 'n volk se lewensopvatting druk en vanuit geloof word 'n lewenspatroon ontwikkel wat as Godgegewe erfenis beskou word en aan nageslagte oorgegee word. Geloof in God gaan egter gepaard met 'n verhouding met God - en die beeldskap van God word in terme van hierdie verhouding verklaar:

[D]ie menswaardigheid van die mens is die vrug van sy verbondenheid met God, die skepper-heer, en hier by hierdie primitiewe volke was nie die minste sprake van 'n Godsbegrip nie en daarom is dit dat die mens hier sy menswaardigheid verloor het, tot so 'n mate, dat daar soms twyfel bestaan het of hulle ooit weer 'n Godsbesef kon ontwikkel en ooit weer hulle menswaardigheid terug kon vind.

(Wolmarans 1962:83)

Dit blyk dat die menswaardigheid van die mens as beeld van God berus op geloof in God en dat nie alles rasse in staat is tot hierdie geloof nie. Die implikasie is dus dat nie alle rasse menswaardig is nie en dat alle rasse nie na die beeld van God geskep is nie. Volgens hierdie argument word die beeldskap van God deur die mens toegeken en ontneem op grond van kontingente faktore soos bevolkingsgroep/kultuur/taal/ intellek. Dit kom daarop neer dat die beeld van God in die mens 'n menslik-bepaalde faktor is. Laasgenoemde berus duidelik op 'n optimisme oor die mens se vermoë tot kennis en waarheid. Die onbeholpenheid met verskeidenheid word deur bepaalde ideologieë gekamoefleer, soos dit duidelik blyk uit die volgende opmerkings van Wolmarans (1962):

\footnotetext{
... alleen namate die Afrikaner losgemaak kan word van sy oorgeërfde lewensopvatting, wat skriftuurlik gefondeer is, na die mate sal daar minder verskille oorbly tussen sy rassebeleid en die liberalistiese opvattings van die kultuurprotestantisme van die Anglikaanse religieuse filosofie, wat vandag sy stempel druk op die hele Wêreldraad van Kerke en deur hierdie volslae liberalisties-etiese liggaam op die hele protestantse wêreld van vandag.
}

(Wolmarans 1962:84)

Die Suid-Afrikaanse pionier ... wie se hele lewensuitsig as Calvinis gegrond was in die liggewende krag van die Woord van God in die Skrif ... het geweet dat as hy hierdie skriftuurlike gefondeerheid van sy rassebeleid sou prysgee hy daarmee sy hele lewensfondament onder sy voete sal laat uitskop.

(Wolmarans 1962:85)

Soos aangetoon in die eerste artikel (kyk Van Wyk \& Buitendag 2011) het S.P. Engelbrecht, A.J.G. Oosthuizen en J.M.G. Dreyer dieselfde sentimente gehuldig en die voortgesette regverdiging van aparte volkskerke en afsonderlike ontwikkeling voortdurend hierop gegrond.
Dit is as 'n appèl op die bestaan van die verskeidenheid van menswees gekamoefleer. Ook is aangetoon dat die gronde vir hierdie regverdiging berus het op die beginsel van 'geengelykstelling' - gegrond in ' $n$ positiwistiese epistemologie wat uitgemond het in aannames aangaande die wese van die mens (ontologies). Hierdie erfenis is steeds deel van die NHKA (vgl. Buitendag 1999:335).

Dit word gesien in die spanning oor die verstaan van inklusiwiteit en diversiteit in die NHKA. Die Beswaarskrif wat deur die Komitee van Beswaardes (2011) uitgereik is, bou voort op die argumente van destyds. Daar word steeds verklaar dat die beeldskap van God uitsluitlik gegrond is op 'n verhouding met God. Per implikasie beteken dit dus dat die mens wat nie in die 'regte' verhouding met God is nie, nie na die beeld van God geskep is nie. Die positiwistiese kenteorie steek hier weer kop uit. In die Beswaarskrif word dit ook gestel dat die mens nie 'n eienskap aan homself (outeur se eie beklemtoning) buite-om God kan toeken wat slegs deur God (in die regte verhouding met God) toegeken kan word nie. Hierdie stelling is, in die lig van die vorige opmerkings, 'n contradictio in terminis.

In die NHKA se verstaan en hantering van homoseksuele persone kom daar nog 'n teenstelling na vore, naamlik die aanvaarding van die homoseksuele mens maar die afwysing van 'n seksdaad. In die agenda van die 67ste Algemene Kerkvergadering (AKV) is dit gestel dat: "n Geïsoleerde homoseksuele oriëntasie sonder homoseksuele aktiwiteit word nie afgekeur nie. Dieselfde-geslag-seks binne so 'n verhouding, met wat daarmee saamgaan, is egter nie aanvaarbaar nie' (NHKA 2004:392).

Dit blyk dat die NHKA heteroseksuele aktiwiteite as die enigste werklike en aanvaarbare seks voorhou. Die mens word verdeel in persoon en optrede (siel en liggaam; leer en lewe) en word getakseer, verstaan en hanteer op grond van 'een van die dele'. Menswees word gereduseer tot daardie gedeelte. In die geval van homoseksuele persone word hulle ' $n$ wesenseienskap van sy of haar menswees ontneem. Homoseksuele aktiwiteite is dus per definisie gestigmatiseer, aangesien homoseksuele dade gelykgestel word aan dade of gewoontes van alkoholmisbruik en diefstal. Genetiese predisposisie word hoegenaamd nie erken nie:

Dit is ook foutief om die verskoning vir homoseksualisme voor te hou waar die gene die skuld kry omrede die persoon wat hieraan onderwerp is, 'daar niks aan kan doen nie'. 'n Alkohol misbruiker of habituele winkeldief of owerspelige mens of leuenaar of verskeie ander gedragsafwykende persone kan dieselfde soort verskonende argument opwerp om so aanvaarding te probeer vind.

(NHKA 2004:393, [outeur se eie beklemtoning])

Bogenoemde word verder bevestig in die Besluitebundel van die 68ste AKV. Die besluite geneem oor die 26ste en 27ste beskrywingspunte lees onder meer:

Die Kerk moet in die hantering van die omvattende seksuele verskynsel die heteroseksuele huwelik koester en beskerm as die enigste huweliksvorm soos deur God self ingestel. Dit is die enigste ruimte volgens die Skrif waarbinne seksuele aktiwiteite, 
familiebou en gesinsgroei kan voorkom. ... Persone met 'n homoseksuele oriëntering het die verantwoordelikheid om hulle te weerhou van homoseksuele gedrag net soos alle ander mense ten opsigte van hulle gebroke menslike natuur selfbeheersing moet beoefen ... Die Kerk bevestig dat homoseksueel georiënteerde persone wat selibaat lewe, tot die ampte van die Kerk toegelaat word.

(NHKA 2007:47-48)

Die NHKA se beginsel van 'geen gelykstelling' is gegrond op ' $n$ bepaalde verstaan van die wese van die mens. Dit kan by wyse van analogie met 'n rekenkundige optelsom as 'n algoritme beskryf word. 'n Konsep van geen gelykstelling berus intrinsiek op ' $n$ bepaalde rangorde van menswees; 'geen gelykstelling' impliseer 'nie-op-dieselfde-vlak nie'. 'Geen gelykstelling' kan dus geregverdig word met die empiriese verskeidenheid van die mens. Hierdie rangorde berus op die mens wat die somtotaal van 'n optelsom/ definisie gemaak word, naamlik: mens $=$ ? + ? + Die NHKA se beleid van 'geen gelykstelling' maak die volgende som of definisie: mens = liggaam (velkleur + geslag + seksualiteit + daad $)+$ siel $($ rede + taal). Die fragmentasie in mensbeskouing vind elke keer plaas as daar op een van hierdie elemente/ komponente/fragmente gefokus word en in terme van 'geen gelykstelling' 'n rangorde toegeken word. Nie net word daar kenteoreties nie, maar ook in terme van die verstaan van die ontologie van die mens, positiwisties omgegaan met die werklikheid. Dit verskraal die mens tot die totaal van die rekenkundige som. En aangesien die beginsel van 'geen gelykstelling' in die NHKA gehandhaaf is om ekklesiologie te bepaal, het dit gelei tot 'n gefragmenteerde ekklesiologie. Die verskraling in die verstaan van menswees het gelei tot 'n gereduseerde, gefragmenteerde, eksklusiewe ekklesiologie waarin die NHKA soos 'n volstruis kop in die sand steek (analogie waarna bo in die aanhaling van Piaget verwys is) en nie bewus wil wees van die omringende omgewing nie.

\section{Mens = die totaal is meer as die som van die dele Bybelse perspektiewe}

Green (1998:151) is van oordeel dat die Christelike tradisie geneig is om 'n antropologiese dualisme te aanvaar (vgl. Nee 1968). 'n Voorbeeld van laasgenoemde word onder meer in die New Revised Standard Version (NRSV), die King James Study Bible (KJSB) en die Ou Afrikaanse Vertaling (OAV) van die Bybel in Openbaring 18:12-13 aangetref. Johannes gebruik die luukse en waardevolle inhoud van 'n vragskip wat op pad is na Rome as metafoor vir die Romeinse Ryk se verval en eksploitasie deur dit te vergelyk met ' $n$ minnares se luukse en weelderige lewe ten koste van haar minnaars. Saam met goud, silwer, fyn linne en ander luukshede wat in die skip is, is daar ook stomatoi kai psychas anthropon. Die NRSV vertaal dit as 'slaves and human lives', die KJSB as 'slaves and the souls of humans' en die OAV as 'slawe en die lewens van mense'. Arndt en Gingrich (1985:799) meen die Grieks kan letterlik vertaal word as 'liggame, selfs die siele van mense'. Green (1998:130) oordeel dat hierdie vertalings tekenend is van die teenwoordigheid van die liggaam-siel dualisme in die Grieks-Romeinse milieu; dit illustreer die verwringing wat kan voortvloei uit 'n dualistiese verstaan van die mens, omdat selfs slawe meer as net hul fisiese liggame was en hulle op grond daarvan verkeerdelik (volgens bogenoemde voorbeeld) saam met karkasse en vee en skape geklassifiseer is. Die vraag op hande is dus of die oorsprong van die gefragmenteerde mensbeskouing uit die Bybel geregverdig kan word.

In die $\mathrm{Ou}$ Testament in Genesis word die skepping van die mens as Imago Dei in verband gebring met die mens se uniekheid teenoor diere (Ayala 1998:31). Elders word die Hebreeuse begrippe nephesh (Gen 1:12, 2:7; Lev 2:1, 4:2) en basar (Jes 10:18; Ps 119:73) in verband met die mens gebruik. ${ }^{2}$ Nephesh verwys na die holistiese mens as setel van begeertes en emosies en kan vertaal word met die term persoon (Green 1998:150; vgl. Botterweck \& Ringgren 1975:311332; Holladay 1988:51). Basar word dikwels parallel en nie teenoor nephesh gebruik nie. Dit kan na die vleeslike aspek van die persoon verwys, maar kan ook as uitdrukking van die spirituele aspek gebruik word (Green 1998:150; vgl. Botterweck \& Ringgren 1975:311-332; Holladay 1988:242). Green (1998:158) meen dat beide hierdie begrippe verstaan word as verskillende aspekte van die mens se eksistensie as 'n tweevoudige eenheid en aangewend is om die mens as geïntegreerde geheel te verstaan en te beskryf. Hiervolgens besit die mens nie ' $n$ liggaam en siel nie, die mens is mens as liggaam en siel. Die Ou Testament beklemtoon die feit dat die mens uniek is. Dit word beklemtoon deur die herhaalde gebruik van sogenaamde 'ons-taal' en die verwysing na die mens as Imago Dei in Genesis. Die mens se uniekheid teenoor die res van die skepping word nie in 'n dogmatiese uitdrukking aangaande ' $n$ onbeliggaamde siel geplaas nie. Die karakter van die mensdom as God se verbondgenoot word eerder beklemtoon (Breytenbach 1984:4-6; vgl. Van Wyk \& Buitendag 2010).

Wat die Nuwe Testament betref word daar veral gewys op insigte oor die verstaan van die mens in Pauliniese geskrifte. Die redes daarvoor is dat Paulus in sy sendingreise bekend geraak het met verskeie aspekte van die Griekse filosofie (kyk bv. Hand 17:16-33), en ook daardeur beïnvloed was. Paulus het in sy briefwisseling met die gemeente in Korinte uitvoerig oor die begrip liggaam geskryf na aanleiding van bepaalde gedagtes wat rondom die siel en liggaam in genoemde gemeente bestaan het, veral ten opsigte van die opstanding van die liggaam na die dood (1 Kor 15), die huwelik, en die selibaat (Van Aarde 2005b:82). In 1 Korintiërs 12 word die Pauliniese metafoor 'die liggaam van Christus' aangetref.

Die begrippe sarks en soma word in 1 Korintiërs 15:35-58 en in Romeine 1:26-27 in verband met die mens se wese of bestaan gebruik. Volgens Aland et al. (1998:177) verwys beide na die liggaam. In die Pauliniese teologie is daar egter duidelike aksentverskille wat die twee begrippe betref (Van Aarde 2005b:153). Paulus verstaan onder die begrip sarks die vlees, verganklike feilbare menswees. Die mens wat leef volgens die Gees van God (pneuma) hou op om sarks te wees verwys om aan te toon dat die begrippe wel in verband met die mens gebruik word. 
en oorstyg wat Paulus die sarkikos-bestaan noem. Vir hierdie bestaan gebruik Paulus die begrip soma as verwysend na die pneumatiese mens en noem dit die somatiese - of psuchikosbestaan van die mens. Die sarks word dikwels negatief deur Paulus beoordeel (Edwards 1996:69). ${ }^{3}$ Dreyer (2004:180) meen dat Paulus na die sarks in 'n negatiewe sin verwys omdat hy dit gesien het as die oorsaak dat mense uit swakheid sonde doen. Edwards (1996:74) meen egter dat die verkleinerende wyse waarop Paulus van die sarks praat bygedra het tot 'n dualistiese antropologie, soortgelyk aan die Griekse filosofie, waarin die siel beskou is as vasgevang in die bose liggaam van die vlees (Edwards 1996:74). Dreyer (2004:180) verskil hiervan en verklaar dat hierdie tipe argumentvoering die konklusie meebring dat homofobie ${ }^{4}$ en sarkofobie op grond van die evangelie geregverdig word. Laasgenoemde is die gevolg van die eensydige beklemtoning op Paulus se negatiewe beligting van die sarks. Paulus gebruik egter die begrip soma teenoor dié van sarks. Eersgenoemde verwys na liggaam, en in die besonder gebruik Paulus die begrip 'kata pneuma' om te verwys na die bestaan van die mens wat lewe volgens die Gees van God. Die pneumatiese mens oorstyg die mens se sarkikos-bestaan. Die onderskeid wat Paulus tussen die pneuma en die sarks maak dui juis daarop dat die sarks nie opgehef word nie, maar diensbaar gestel word aan God. Wanneer Paulus dus van die kerk as die soma van Christus praat, bedoel hy die ruimte waar die pneumatiese mens lewe, ten spyte van die sarkikos-bestaan (Van Aarde 2005b:162153). Paulus praat nie gefragmenteerd oor die mens nie, eerder allesomvattend (holisties). Laasgenoemde kom veral tot uitdrukking in 1 Korintiërs 15:16-52 waarin Paulus skryf oor die aard van die opstandingsliggaam.

Green (1998:172) kom tot die gevolgtrekking dat diverse invloede gegeld het in die vorming van die Nuwe Testamentiese verstaan van die mens, veral soos dit in die teologie van Paulus uitkristalliseer. Net soos in die $\mathrm{Ou}$ Testament is die dominante verstaan van die mens gesetel in 'n ontologiese monisme. Green verklaar dat konsepte soos 'ontsnapping van die liggaam' en 'onbeliggaamde siel' buite die parameters van die Bybelse verstaan van die mens val. Eerder is dit die ontwikkelende tradisie van die Christelike teologie en Bybelse interpretasies, as Bybelse teologie, wat die katalisator was (en is) vir 'n gefragmenteerde verstaan van die mens. Hierin kan die invloed van die Griekse filosofie ${ }^{5}$ nie gering geskat word nie, en moet dit gestel word dat

3.Volgens Van Aarde (2005b:152, vgl. Edwards 1996:70-71; Schweizer 1971:125-135) is daar verskeie kategorieë van Paulus se gebruik van sarks in sy briewe waaruit die negatiewe beoordeling van die sarks blyk:

- Kata sarka - volgens die vlees. Dit word in verband gebring met die mens se afkoms, maar dit word ook negatief gebruik in terme van die mens se self-gesentreerde aktiwiteite.

- En te sarki - in die vlees. Dit verwys na die substansie van die vlees; ook na die fisiese bestaan van die mens in hierdie lewe en werklikheid (Gal 2:20).

- Sarks as objek van vertroue en in hierdie sin is dit nie die sarks wat sondig is nie, maar eerder die optimisme aangaande die moontlikhede van die sarks.

- Dit word in teenstelling met begrippe soos pneuma en nous gebruik.

- Die verslane sarks. Hiervolgens is die sarks gekruisig - 'n herhalende tema in Pauliniese teologie (Schweizer 1971:130)

4.Die term is die eerste keer in 1972 gebruik deur die Amerikaanse sielkundige George Weinberg, en dui op ' $n$ intellektuele ongegronde vrees vir homoseksualiteit wat to uiting kom in negatiewe emosies en lei tot diskriminerende gedrag teenoor persone wat homoseksueel georiënteerd is (Müller in Gaum 2008:470).

5.Die terme Griekse filosofie word hier as oorkoepelende term gebruik vir die bespreking oor die Griekse filosofie bo en met die gebruik daarvan word geensins voorgestel dat 'Griekse filosofie' net een denkrigting of -stroom behels nie. laasgenoemde in werklikheid 'n groter rol as byvoorbeeld Paulus se teologie speel in die vorming van teologiese antropologiese kontoere.

\section{Ander perspektiewe}

Die Griekse filosofie het die mens gefragmenteer, oftewel, in dele verdeel. Die gevaar van hierdie fragmentasie (soos bo aangetoon) is dat een van die sogenaamde dele oorbeklemtoon word, of dat die holistiese mens tot een van die sogenaamde dele gereduseer word. Eersgenoemde kom neer op 'n dualisme en laasgenoemde op 'n reduktiewe materialisme. Die dualistiese verstaan van die mens word geillustreer in die volgende uitspraak van John Eccles wat 'n dualisme ten opsigte van menswees bepleit: 'Let us be quite clear that for each of us the primary reality is our consciousness - everything else is derivative and has a second order reality' (Eccles in Murphy 1998:88). Frances Crick, hierteenoor, bepleit 'n reduktiewe materialisme teenoor die dualisme: 'you are nothing more than a pack of neurons ... no more than the behavior of a vast assembly of nerve cells and their associated molecules' (Crick in Murphy 1998:89). Hy beskou die werklikheid as konsekwent materialisties.

Teenoor beide die dualisme en die reduktiewe materialisme as mensverstaan en werklikheidsverstaan, postuleer Nancey Murphy (1998:2, 127-129) 'n non-reduktiewe fisikaliteit. Hierdie verstaan van die mens is afkomstig vanuit die insigte van die neuro- en kognitiewe wetenskappe, en het volgens Murphy in 'n sekere sin die Darwiniaanse revolusie voltooi in die sin dat die menslike bewussyn (mind) en die menslike liggaam nou saam in die sfeer van wetenskaplike navorsing geplaas is.

Fisikaliteit op sigself dui op 'n reduktiewe verstaan van die mens omdat dit stel dat die mens se gedrag breedvoerig deur genetika en neuro-biologie verklaar kan word. Nonreduktiewe fisikaliteit is hiervoor ' $n$ alternatief; nie net vir die dualisme en reduktiewe materialisme nie, maar ook as 'n middeweg tussen die Bybelse monisme en die dualisme (Buitendag 2004:68,77), asook die verwerping van filosofiese argumente dat die mens niks anders as ' $\mathrm{n}$ liggaam is nie. Dit dui op die verstaan van die mens as fisiese organisme met komplekse funksionering. Die mens as liggaam word erken, maar daarmee saam word ander menslike kapasiteite wat ook essensieel is vir menslikheid erken: rasionaliteit; emosie; die vermoë om keuses te maak, moraliteit en die vermoë om met God in 'n verhouding te wees - die sogenaamde hoër menslike kapasiteite (Murphy 1998:2).

\section{Die mens: Die geheel is meer as die totaal van die som van die dele}

Die non-reduktiewe fisikaliteit erken die komplekse funksionering van die mens. Hierdie erkenning is slegs moontlik in terme van 'n meervlakkige, dinamiese verstaan van die werklikheid. Arthur Peacocke (1996:43) klassifiseer dit soos volg: (1) fisiese werklikheid; (2) biologiese werklikheid; (3) gedragswerklikheid en (4) kulturele werklikheid. 
Met die kloning van Dolly die skaap en die kartering van die menslike genoom, ${ }^{6}$ en by name die spesifieke volgorde van die vier basiese pare nukleotides in die menslike gene (Adenien, Tiamien, Sitosien en Guanien) ontstaan die vraag: 'Do genes make us who we are?' (Anderson 1998:49). Buitendag (2004:61-81) vra ook die vraag: 'Genes Я us - of juis nie?' Hierdie tipe vrae bring daarmee saam ' $n$ bepaalde fatalisme, want as die biologiese of genetiese aard van die mens in isolasie verstaan word, dui dit op 'n bepaalde determinisme wat die mens predisponeer: 'If it is genetic, what can we do about it?' (Anderson 1994: 758).

Om hierdie soort fatalisme en determinisme te voorkom, stel Anderson (1998:50) 'n meer uitgebreide genetiese verstaan van die mens voor wat genetiese èn omgewingsfaktore in die studie van die menslike gedrag verdiskonteer (Loehlin 1992:105-111; Holdrege 1996). Genotipe-omgewings korrelasie verwys na situasies waarin gene-tipes verskillend aan verskillende omgewings blootgestel word. So sal sommige kinders byvoorbeeld van hul ouers gunstige gene saam met 'n ondersteunende omgewing ontvang, terwyl ander kinders ' $n$ minder gunstige genetiese bedeling tesame met ' $n$ neutrale of ongunstige omgewingsituasie sal ontvang. Dus, genetiese-omgewingsinteraksie lei tot verskillende reaksies op verskillende omgewings. Anderson (1994:54-57; vgl. Holdrege 1996; Buitendag 2004:77) bied die volgende insigte uit genetiese navorsing aan:

- Gene handel nie geïsoleerd nie. Die ontwikkelende embrio is voortdurend blootgestel aan eksterne faktore (bv. voeding deur die moeder) en ook aan die handeling van ander gene. Menslike eienskappe is multifaktoriaal en verteenwoordigend van die gekombineerde effek van gene tesame met interne en eksterne omgewingsfaktore.

- Gene se aktiwiteit is altyd indirek. Anderson stel die analogie voor van gene wat 'n bloudruk is. Soos die planne van 'n gebou, vra die bloudruk van die genoom ${ }^{7}$ om geïnterpreteer te word.

- Gene kan aan- en afgeskakel word. Navorsing het getoon dat daar tot 80000 gene in die menslike genoom is en dat daar in enige gegewe sel slegs ' $n$ klein aantal van die gene teenwoordig aktief is. Sekere gene is slegs aktief in sekere weefsel, byvoorbeeld die lewer en die brein. Ten spyte van monosigotiese tweelinge se identiese stel gene, is die ontwikkeling daarvan verskillend. Selle kan gekloon word, maar nie die mens nie (vgl. Buitendag 2004:77).

- Gene kan op verskillende tye gedurende ontwikkeling handel. Hoewel daar ' $n$ bepaalde volgorde in die ontwikkeling van die embrio is, is dit belangrik om daarop te let dat gene uit die breinstam migreer en dan wegraak.

- Gene en die omgewing se interaksie met mekaar duur voort regdeur die mens se lewe.

Al die bogenoemde aspekte spreek mee en bepaal die werking van die gene:

6.Die suksesvolle kartering van die menslike genoom is op 14 April 2003 deur die International Human Genome Sequencing Consortium onder leiding van die National Human Genome Research Institute en die Department of Energy in die VSA aangekondig (kyk webblad van die tydskrif Nature, te wete http://www.nature. com/nature/DNA50).

7.Die term genoom verwys na ' $n$ volledig stel gene (Anderson 1998:54).
In ontogenesis, the genetic and nongenetic factors interact in producing successive stages, each of which is the prerequisite and determines the conditions for the next one to follow. In this interplay, genes are a necessary, but not sufficient component. The structures already present, gradients, threshold values, positional relationships and conditions of the internal milieu are equally essential.

(Wolf 1995:127)

Op die vraag of die mens gedetermineer word deur gene antwoord Anderson (1998:69) dat die mens se handelinge en optrede op 'n kontinuum lê tussen algehele vryheid en algehele determinisme. Gedurende 'n persoon se ontwikkeling word die patroon van genetiese uitdrukking en onderdrukking voortdurend aangepas by omgewingsfaktore en ander lewensomstandighede. Die mens skep sy of haar vryheid in omgang met die omgewing, terwyl die mens se gene en die omgewing as bronne tot die mens se beskikking vir hierdie interaksie aangewend word. Die eenvoudige en terselfdertyd komplekse aard van DNS (deoksiribonukleïensuur) beteken tegelyk die eenheid en die verskeidenheid (individualiteit) van die mens. Die mens is as gevolg van die menslike genoom tegelyk uniek en verbind met ander. Hierdie eenheid en verskeidenheid het implikasies vir die wyse waarop moraliteit en spiritualiteit beskou word.

In die lig van die resultate van navorsing oor die biologie en genetika van die mens ontstaan die volgende vraag: wat beïnloed die mens se kapasiteit om waardeoordele te vel? Om keuses te maak? Volgens Cole-Turner (1993:88-89) word die mens se moontlikheid vir morele en spirituele handelinge geneties gekondisioneer, maar die mens se gebruik daarvan bly ' $n$ saak van persoonlike keuse. Dit kan voorlopig gestel word dat die mens se vermoë tot moraliteit en spiritualiteit dus aan sowel genetiese- en omgewingsfaktore te wyte is. Ayala (1998:25) voeg hierby nog 'n faktor, te wete kultuur; die kulturele evolusie van die mens transendeer die biologiese evolusie van die mens. Dit word geillustreer deur die mens se kapasiteit tot morele keuses. Die moontlikheid om morele oordele te vel is volgens Ayala afkomstig van drie ontwikkelinge wat elkeen hoë oorlewingswaarde gehad het:

- die vermoë om handelinge se konsekwensies te antisipeer

- die vermoë om waarde-oordele te maak

- die vermoë om tussen verskillende handelswyses te onderskei.

Dit beteken dat die biologiese geneigdheid om waardeoordele te maak eers tot etiese gedrag omgesit kan word wanneer dit deur moraal (nie-biologies) gekomplementeer word. In teenstelling met die insigte van evolusioniste, wat die inhoud van moraliteit reduseer tot dit wat noodsaaklik is vir die oorlewing van die mens, beklemtoon Ayala dat die aard van die mens meer omvattend as net biologie is. ' $n$ Vollediger verstaan van die mens moet volgens hom die twee dimensies van menswees integreer, naamlik die biologiese en die kulturele.

Tillich (1964:188) het ook die konteks van die kultuur in die verstaan van die mens beklemtoon, en is van mening dat wanneer die mens ' $n$ besluit maak dit die konkrete geheel is 
wat inspraak lewer, nie net die individu nie. Kultuur bring waardes en norme voort. Kultuur sluit politieke en sosiale dimensies in, tesame met godsdienstige en etiese tradisies, taal en wetenskaplike kennis, kuns en literatuur - alles wat skeppings van die menslike bewussyn (mind) is (Anderson 1998:38). Kultuur bring waardes en moraal voort. Kultuur is juis kultuur omdat dit 'n bepaalde vryheid voorstel (Hefner 1993:158).

SekereChristengelowiges sal vanuithulwerklikheidsverstaan wil byvoeg dat dit God se progressiewe openbaring aan die mensdom is wat op 'n deurlopende basis die ontwikkeling van die menslike kultuur en -gemeenskap beïnvloed. Die begrippe van erfsonde en die mens se vrye wil hou ook hiermee verband, aangesien dit hier handel oor die mens se kapasiteit om waardeoordele te maak. Die vraag wat gevra word, is of die erfsonde hoegenaamd die teologiese keersy van die genetiese determinisme is (vgl. Buitendag 2004:71). Calvyn se beskrywing van die erfsonde in sy Institusie II.1.4 kommunikeer dat die mens se natuur (aard) tot sonde gepredisponeer is. In hierdie saak is hy deur Augustinus beïnvloed (McGrath 2001). Daarvolgens kan die mens self niks doen aan 'n natuurlike geneigdheid om sonde te doen nie. Tillich (1999:167) beskou erfsonde egter as die basiese vervreemding van die mens voor God wat alleen deur 'n verhouding van genade oorkom kan word. Erfsonde moet dus nie bloot biologies of sosiaal verstaan word nie. Al tree die brein volgens reëls op, is die interaksie van die menslike persoon binne' $n$ bepaalde konteks oop en vry (kyk Buitendag 2004:71).

In hierdie opsig is dit die Imago Dei wat die mens in die skepping uniek maak. Hierdie beeld is sowel substansieel as relasioneel te verstaan (Buitendag 2011:15). Die beeldskap is nie gegrond op die relasie (verhouding) nie, maar kom tot uitdrukking in verhoudings as intrinsieke etiese appèl waar die deugde van die mens deur die radikale liefde van Christus gevorm word.

Brown (1998:124) vind die vermoë van die mens tot persoonlike verwantskap (in-relasie-wees) in die konsep van die siel. Hierdie vermoë van die mens vind hy nie op dualistiese of gefragmenteerde wyse in 'n aparte deel van die mens nie, maar eerder in die mens se kognitiewe vermoëns. Die kognitiewe vermoëns wat hierdie kapasiteit vir relasies moontlik maak is taal, ' $n$ konsep van ander bewussyne (minds), episodiese geheue, toekomstige oriëntasie en emosionele modulasie van sosiale gedrag. Die siel van die mens is dus volgens Brown die mens se vermoë om met die self, ander mense en God in relasie te tree. Sy slotsom is dat, hoewel kognisie tot die siel bydra, dit God se handeling van relasie is wat die siel in elke mens voortbring (Brown 1998:125).

Die gevolgtrekking is dat die mens nie bloot in terme van natuur(biologie), of kultuur, of diemens seomgewingsfaktore, of geneigdheid tot sonde, gedefinieer kan word nie. Seksuele gedrag kan byvoorbeeld (as deel van die mens, nie apart nie) ook nie net aan biologie toegeskryf word nie. Dit word gevorm deur ' $n$ ingewikkelde mengsel van rolverwagtings en kulturele simbole wat in wisselwerking met psigiese faktore is. Volgens Dreyer (2006:464) het vroeëre sienings aangaande biologiese determinisme plek gemaak vir sienings wat sosiokulturele faktore in ag neem (Stone 2000:234-235).

Eksistensie realiseer binne 'n bepaalde sosio-linguistiese raam of nis waar bepaalde oortuigings en moraliteit geld en wat ook deur godsdiens beïnvloed kan word. Mens-wees is 'n wisselwerking van enkeling en groep, tradisie en ervaring, biologie en kultuur, en alleen binne hierdie raamwerk is die mens werklik mens (Buitendag 2004:76). Die mens is dus meer as die somtotaal van verskillende dele. Om 'n persoon gelyk te stel, te takseer, te probeer plaas, te probeer verstaan of selfs te beskryf in terme van biologie, of taal, of velkleur of seksualiteit of geslag of kulturele agtergrond of selfs die suggestie van die mens se vermoë tot keuse in hierdie sake, kom neer op 'n reduktiewe en deterministiese verstaan van die mens.

Die weg is gebaan dat daar voortaan konsekwent van die menslike persoon gepraat sal kan word. Dit omvat die totale mens in al sy of haar bio-kulturele geledinge (Buitendag 2004:74).

\section{Steedsroepend, steedsversoenend, steedshervormend}

Fragmentasie neem spasie (ruimte) in beslag. Hoe meer daar gefragmenteer word, hoe minder spasie is daar om die geheel te stoor, en word die geheel verder gefragmenteer om in beskikbare ruimte(s) in te pas. Defragmentasie is die proses van oopmaak van spasie. Dit is dus duidelik dat die konsep van fragmentasie baie nou verband hou met die konsep van spasie.

Cilliers (2007:73-87) beskryf liminale spasie as 'op-reis-wees': jy het jou huis verlaat, maar jy is nog nie by jou bestemming nie (Tournier 1968:163). Dit impliseer 'n pelgrimstog wat uiteindelik lei dit tot die vorming van 'n nuwe gemeenskap. In hierdie nuwe gemeenskap is ' $n$ nuwe kombinasie van vorms en nuwe relasies uiteraard die geval.

Die sistematiese teoloog, Jürgen Moltmann, het op 80-jarige leeftyd sy outobiografie geskryf, getiteld Weiter Raum: Eine Lebensgeschichte (2006) (Engels: A broad place, Moltmann 2008). Hy interpreteer 'breë spasie' as die uitdrukking van die Triniteit: God word nie gereduseer tot een konsep nie. Al drie persone van die Triniteit is altyd betrokke. Hierbinne laat die drie Persone van die Triniteit op uitnodigende wyse wedersydse ruimte vir beweging (Moltmann 2008:285303). Binne hierdie ruimte is daar eenheid-in-diversiteit, gemeenskap en andersheid - 'n ruimte wat as a broad place beskryf kan word.

Die geskiedenis van die NHKA toon 'n onvermoë om in 'n breë spasie kerk te wees as gevolg van 'n ongemak met die ander (autrè). Daar is 'n ongemak met die ander omdat menswees gelykgestel word aan die korrekte dele van die 
som. Hierdie fragmentasie reduseer die breë spasie van die kerk juis omdat dit spasie in beslag neem. As daar nie spasie is nie, kan daar nie gereis word nie - want ' $n$ reis impliseer dat ' $n$ afstand tussen twee punte afgelê word, dit impliseer ' $n$ uitwaartse beweging vanaf 'n oriëntasiepunt. As daar geen spasie is nie, is daar nie plek vir beweging nie. Die grondslag van die NHKA se identiteit is juis ' $n$ voortdurende beweging, 'n op-reis-wees, soos die bekende spreuk ecclesia reformata semper reformanda aandui. 'n Hervormde kerk moet altyd weer hervorm. ' $n$ Hervormde Kerk moet altyd die spasie laat uitkring. Dingemans (2001:271) beskryf hierdie uitkringende spasie in terme van 'n ronde tafel, waarnatoe almal uitgenooi word en geroep word om aan te sit. Die NHKA se identiteit berus egter ook op die geroepenheid om die evangelie van Jesus Christus te verkondig - en die evangelie is inklusief:

Whenever we are presented with a choice between being biblical and being inclusive, it is a false dichotomy - for to be truly biblical is to be inclusive in any community which wants to follow and imitate Jesus.

(Burridge 2007:409)

Dit beteken dat die NHKA juis nie 'steedshervormd' moet wees nie (met verwysing na die Komitee van Beswaardes se identifikasie); maar om in terme van die teenwoordige deelwoord, juis steedshervormend te wees; dit beteken om steedsroepende en steedsversoenende te wees - en dit is 'n nimmereindigende reis. Die NHKA se voortsetting van hierdie reis noodsaak egter introspeksie, want:

it is not a view of the nonmaterial soul that shapes and drives Christian ethics. Instead, the image of Christ's love properly appreciated will hopefully permeate any anthropology with the power of its insistence on radical inclusivity ... ultimately this love is sustained by the conviction that at the centre of the universe there exists a caring God, revealed in the love of Jesus Christ toward even the least among us.

(Post 1994:21)

Die NHKA het wel al die reis begin - daarvan getuig die talle groeipyne in die Kerk. Om 'n oop ruimte, 'n 'breë plek' van inklusiewe liefde te wees, is dit egter nodig dat die NHKA de-fragmenteer om sodoende weer die spasie oop te maak.

Die evangeliese appèl is daar en die reis duur voort.

\section{Erkenning \\ Mededingende belange}

Die outeure verklaar dat hulle geen finansiële of persoonlike verbintenis het met enige party wat hulle nadelig kon beïnvloed in die skryf van hierdie artikel.

\section{Literatuurverwysings}

Ackrill, J.L., 1997, Essays on Plato and Aristotle, Clarendon Press, Oxford.

Aland, K., Black, M., Martini, C.M., Metzger, B.M., \& Wikgren, A., 1998, The Greek New Testament, 4th edn., Deutsche Bibelgesellschaft, Stuttgart.

Allen, D., 1985, Philosophy for understanding theology, John Knox Press, Atlanta.

Anderson, F.W., 1994, 'Genetic engineering and our humanness', Human Genome Therapy 5, 785-759.

Anderson, V.E., 1998, 'A genetic view of human nature', in W.S. Brown, N. Murphy \& H.N. Malony (eds.), Whatever happened to the soul: Scientific and theological portraits of human nature, pp. 31-48, Fortress Press, Minneapolis.

Aristoteles [350 BCE] [1894] 1962, Ethica Nichomachea, ed. I. Bywater, Aristotels ethica Nichomachea, Clarendon Press, Oxford.
Aristoteles [350 BCE] 2007, Metaphysica (Metaphysics), transl. W.D. Ross, viewed 01 September, from philosophy.eserver.org/aristotle/metaphysics.txt

Aristoteles [350 BCE] 2007, Categoriae (Categories), transl. E.M. Edghill, eBooks@ Adelaide 2007, viewed 01 September 2011, from ebooks.adelaide.edu.au/a/ aristotle/categories

Arndt, W.F., \& Gingrich, F.W., 1958, A Greek-English lexicon of the New Testament and other early Christian literature, 2nd edn., University of Chicago Press, Chigaco.

Augustinus [2003], De bono coniugali, in B.J. Brooten 2003, 'Nature, law, and custom in Augustine's On the good of marriage', in S. Matthews et al. (eds.), Walk in the ways of wisdom: Essays in honor of Elisabeth Schüssler Fiorenza, pp. 181-193, A Continuum imprint, Trinity Press International, Harrisburg, PA.

Ayala, F.J., 1998, 'Human Nature: One evolutionist's view', in W.S. Brown, N. Murphy \& H.N. Malony (eds.), Whatever happened to the soul: Scientific and theological portraits of human nature, pp. 31-48, Fortress Press, Minneapolis.

Blumenfeld, W.J., 1992, Homophobia: How we all pay the price, Beacon Press, Boston.

Børresen, K.E. [1968] 1981, Subordination and equivalence: The nature and role of woman in Augustine and Thomas Aquinas, transl. C.H. Talbot, University Press of America, Washington, DC

Botterweck, G.J. \& Ringgren, H. (eds.), 1975, Theological dictionary of the Old Testament, vol. 2, Eerdmans, Grand Rapids.

Brawley, R.L. (ed.), 1996, Biblical ethics and homosexuality: Listening to scripture, Westminister John Knox Press, Louisville, KY.

Breytenbach, A.P.B., 1984, 'Verbond en verbondstekens in die Ou Testament - 'n terreinverkenning', HTS Teologiese Studies/Theological Studies 40(3), 4-13

Brown, W.S., Murphy N. \& Malony, H.N. (eds.), 1998, Whatever happened to the soul: Scientific and theological portraits of human nature, Fortress Press, Minneapolis.

Buitendag, J., 1999, 'Wat is die Mens?!', in D.J.C. van Wyk (red.), 20ste eeu Hervormde Teologie, pp. 322-338, Sentik, Pretoria.

Buitendag, J., 2004, 'Genes 9 us' - of juis nie? Oor determinisme en voluntarisme by die mens met verwysing na homoseksualiteit', HTS Teologiese Studies/Theological Studies 60(1\&2), 61-81.

Buitendag, J., 2008, Teologie en Filosofie: Studiehandleiding, UP, Pretoria.

Buitendag, J., 2011, 'Die Beeld van God in die mens vanuit 'n sistematies-teologiese perspektief' - Memorandum ingedien ter inligting van die Buitengewone Algemene Kerkvergadering van die NHKA, Oktober 2011, Kerkargief, Pretoria.

Burridge, R.A., 2007, Imitating Jesus: An inclusive approach to New Testament ethics, Eerdmans Publishing Company, Grand Rapids, MI.

Cavadini, J.C., 1999, Augustine through the ages: An encyclopedia, Wim B. Eerdmans, Grand Rapids, MI.

Cilliers, J.H., 2007, 'Preaching as a language op hope', Studia Homeletica 6, 73-87.

Cole-Turner, R., 1993, The New Genesis: Theology and the Genetic Revolution, Westminister John Knox Press, Louisville.

Cornford, F.M., [1935] 1997, Plato's cosmology: The Timaeus of Plato, transl. with a running commentary, Hackett Publishing Company, Inc., Indianapolis.

Dingemans, G.D.J., 2001, De Stem van de Roepende, Uitgeverij Kok, Kampen.

Dogan, M. \& Pahre, R., 1989, 'The fragmentation and re-combination in the social sciences', Studies in comparative international development 24(2), 56-72.

Dreyer, Y., 2004, 'Homoseksualiteit: Die kerk, die tradisie en die Bybel - homofobie en sarkofobie en die evangelie', HTS Teologiese Studies/Theological Studies 60(1\&2), 175-205.

Dreyer, Y., 2006, 'Heteronormatiwiteit, homofobie en homoseksualiteit - ' $n$ roetekaart vir'n inklusiewe kerk', HTS Teologiese Studies/Theological Studies 62(2), 445-471.

Du Toit, C.W., 1996, Nature, God and humanity, UNISA, Pretoria.

Edwards, E.G., 1996, 'Exploring the implications of Paul's use of Sarx (Flesh)', in R.L. Brawley (ed.), Biblical ethics and homosexuality: Listening to scripture, pp. 69-86, Westminister John Knox Press, Louisville, KY.

Eslick, L.J., 1958, 'Substance, change, and causality in Whitehead', Philosophy and Phenomenological Research 18(4), 503-513.

Gerkin, C., 1997, An introduction to pastoral care, Abingdon Press, Nashville, TN.

Gaum, F. (ed.) 2008, Christelike kern-ensiklopedie, Lux Verbi BM, Wellington.

Green, J.B., 1998, 'Bodies - that is, human lives': A re-examination of human nature in the Bible in', W.S. Brown, N. Murphy \& H.N. Malony (eds.), Whatever happened to the soul: Scientific and theological portraits of human nature, pp. 149-174, Fortress Press, Minneapolis.

Hefner, P., 1993, The human factor: Evolution, culture and religion, Fortress Press, Minneapolis.

Holdrege, C., 1996, Genetics and the manipulation of life: The forgotten factor of context, Lindisfarne Press, Hudson, New York.

Holladay, W.L., 1988, A concise Hebrew and Aramaic lexicon of the Old Testament Eerdmans Publishing Company, Grand Rapids.

Jensen, A.S., 2007, Theological hermeneutics, London, SCM Press.

Kantor, M., 1998, Homophobia: Description, development and dynamics of gay bashing, Praeger Publishers, Westport.

Komitee van beswaardes, 2011, 'Beswaarskrif', Agenda vir die buitengewone sitting van die Algemene Kerkvergadering, Oktober 2011, Bylae G, pp. 252-324, Bylae I, 2, pp. 348-359, Pretoria.

Loehlin, J.C., 1992, Genes and environment in personality development, SAGE Publications, California. 
McGrath, A.E., 2001, Christian theology: An introduction, Blackwell, Oxford.

Moltmann, J., 2008, A broad place, Fortress Press, Minneapolis.

Murphy, N., 1998, 'Human nature: Historical, scientific, and religious issues', in W.S Brown N. Murphy \& H.N. Malony (eds.), Whatever happened to the soul: Scientific and theologicalportraits of human nature, pp. 2-30 Fortresse Press, Minneapolis.

Nederduitsch Hervormde Kerk van Afrika (NHKA) 1951, Kerkwet en kerkbepalings van die NHKA, Kerkargief, Pretoria.

NHKA Kommissie van die AKV 2004, Agenda van die 67ste Algemende Kerkvergadering, Kerkargief, Pretoria.

NHKA Kommissie van die AKV, 2007, Agenda van die 68ste Algemene Kerkvergadering, Pretoria, Kerkargief.

Nee, W., 1968, The spiritual man, Christian Fellowship, New York.

Nichols, A., 1998, The word has been abroad: A guide through Balthasar's ethics, T\&T Clark, Edinburgh.

Odendal, F.F. (hoofredakteur) e.a. [1965] 1988, HAT: Verklarende handwoordeboek van die Afrikaanse taal, 2 de uitgawe, $7 \mathrm{de}$ druk, Perskor-Boekdrukkery Johannesburg.

Peacocke, A., 1996, Nature and God: How are we to think of their relation?, in C.W. du Toit (ed.), Nature, God and humanity, pp. 56-72, UNISA, Pretoria.

Piaget, J., 1970, 'The place of the sciences of man in the system of sciences', in Main trends in research in the social and human sciences, Part I: Social Sciences, n.p. Mouton, Paris/The Hague.

Plato [360 BCE] 2004, Timaeus, transl.with an introduction by B. Jowett, eBooks@ Adelaide 2004, viewed 01 September 2011, from ebooks.adelaide.edu.au/p/ plato/p71ti

Plato [360 BCE] [1900] 1967, 'Phaedo', in Platonis Opera, vol. 1, ed. J. Burnett [1900] 1967, Clarendon Press, Oxford.

Post, S.G., 1994, Spheres of love: Toward a new ethic of the family, Southern Methodist University Press, Dallas, Texas.

Ricoeur, P., 1974, The conflict of interpretations, Essays in Hermeneutics, Northwestern University Studies in Phenomenology \& Existential Philosophy, Northwestern University Press, Evanston.
Schweizer, E., 1971, 'Title of Chapter', in R. Kittel (ed.), Theological dictionary to the New Testament, vol. 1, page numbers, Eerdmans Publishing Co, Grand Rapids, MI.

Smith, J.K.A., 2006, Who's afraid of postmodernism? Taking Derrida, Lyotard and Foucault to the church, Baker Academic, Grand Rapids, MI.

Stone, K., 2000, 'Sexuality', in A.K.M. Adam (ed.), Handbook of postmodern biblical interpretation, p. 151, Chalice Press, St Louis.

Storm, J.M.G., 1992, 'Stigters van 'n nuwe land en volk', HTS Teologiese Studies/ Theological Studies 48, 923-941.

Tournier, P., 1968, A place for you, Harper and Row, New York.

Tillich, P., 1999, The essential Tillich: An anthology of the writings of Paul Tillich, ed. F.F. Church, University of Chicago Press, Chicago.

Van Aarde, A., 2005a, Teologiese hermeneutiek: Studiehandleiding, UP, Pretoria.

Van Aarde, A., 2005b, Inleiding tot en teologie van die outentieke briewe van Paulus: NTW (BTh) 451 Studiemateriaal, Universiteit van Pretoria, Pretoria.

Van Aarde, A., 2007, Vanaf die romantiek tot die postmoderniteit: Aantekeninge oor die hermeneutiek, Universiteit van Pretoria, Pretoria.

Van Wyk, D.J.C., 1978, Stemme uit die verlede I, HAUM, Pretoria.

Van Wyk, D.J.C. (jnr), 1999, 20ste eeu Hervormde Teologie, Sentik, Pretoria.

Van Wyk, T., \& Buitendag, J., 2010, 'Die eenheid van die kerk in gedrang', HTS Teologiese Studies/Theological Studies 66(1), Art. \#908, 9 pages. http://dx.doi. org/10.4102/hts.v66i1.908

Vardy, P., 2009, The puzzle of sex, SCM Press, London.

Ward, G., 2003, Postmodernism, Hodder Headline, London.

Wolf, U., 1995, 'The Genetic contribution to the Phenotype', Human Genetics 95(1), 127-148.

Wolmarans, H.P., 1953, 'Die Christelike plig van die Blankes teenoor die Nie-Blankes in Suid-Afrika', in Die Almanak, Kerkargief, Pretoria.

Wolmarans, H.P., 1962, 'Menswaardigheid en menslike regte na aanleiding van die Skrif', HTS Teologiese Studies/Theological Studies 18(3), 83-91. 